\title{
BOGANMELDELSER
}

Christian Diesen, Clara Hellner Gumpert, Frank Lindblad \& Helena Sutorius: Bevis 6 Sexuella övergrepp mot barn. Norstedts Juridik AB. Stockholm 2001. ISBN 91-3920289-5. $226 \mathrm{pp}$.

I det ene af de to forord til denne i sidetal tynde, men i indhold vægtige bog beskrives samarbejdet mellem de fire forfattere som en strygekvartet, hvor de enkelte stemmer er forblevet ulige, men har påvirket hinanden. Recensenten, som er kammermusikelsker og -udøver, kan tiltræde strygekvartettens metafor; det er blevet en harmonisk bog, hvor de fire juridiske og to psykologiske bidrag belyser og nuancerer hinanden fint. Men modsat bogens egen harmoni indeholder den beskrevne virkelighed de mest mislydende dissonanser ved behandlingen af, hvad redaktøren Diesen med fuld ret kalder den måske sværeste sagstype af alle, sager om sædelighedsforbrydelser mod børn (p. 5).

To temaer går igennem hele værket, den miserable sagsbehandling og de dårlige resultater af vidnepsykologernes deltagelse i sagerne. Forf. har ikke blot udslynget påstande, men analyseret et meget betydeligt materiale, Diesen (og stud. jur.er under ham) samtlige anmeldelser i Stockholm i 1996 og 1998 (p. 73 ff.), Sutorius og Diesen hver for sig samtlige domme i fire udvalgte år mellem 1985 og 1997 (p. 169 ff. og p. 201 ff.).

Politi og anklagemyndighed må stå for skud fra Diesen, der betegner den manglende efterforskning efter anmeldelse mod ukendt gerningsmand som "slentrianmässighet" (p. 97) og den omgående slutning af størstedelen af anmeldelser mod kendt gerningsmand, ofte uden udspørgning af barnet, både i disse sager og i sager om vold mod børn, endog når der foreligger partiel tilståelse, som manglende "rättstrygghet" for børn (p. 95). To særlig forsømmelige anklagere sluttede samtlige sager uanset bevisernes vægt (p. 89) jeg håber, at deres overordnede læser bogen, genkender synderne og făr dem flyttet til mindre sårbart arbejde. Med tilbagegangen i sagsantallet in mente har Diesen formentlig ret i, at mange, som dømtes til og med 1992, ikke engang ville blive tiltalt i dag (p. 101).

En ubehagelig, nærmest henkastet oplysning: Af de for vold mod børn mistænkte 91 personer var 50, altså over halvdelen, indvandrere (p. 94). Det må være tilladt at spørge, om politi og anklagemyndighed på forhånd giver op over for andre kulturers syn på passende børneopdragelse.

Også Sutorius advarer i sin omfattende studie Problemorientering vid prövning av sexuella övergrepp mot barn (p. 15 ff.) gentagne gange (pp. 24 f., 49 ff.) imod, at politimænd og anklagere allerede under undersøgelsens tidligere stadier stiller krav næmest om tilstrækkeligt bevis til domfældelse, hvilket betyder, at et stort antal sager opgives på forhånd uden forsøg på efterforskning.

Det andet hovedtema om sam- eller modspil mellem psykologerne og dommerne synes meget præget af eftervirkningerne af en over for anvendelse af vidnepsykologer skeptisk dom NJA 1992, p. 446 og den centrale artikel af justitierådet Torkel Gregow i Svensk Juristtidning 1996, p. 509 ff. Vidnepsykologer anvendes sjældnere end før - i 24\% af alle sager i 1989, i 6\% i 1997 (pp. 141 f., 173) - og kvaliteten af deres arbejde kritiseres stadig mere, ligesom deres nytte for de enkelte sager betvivles efter Gumperts nøje analyse næsten sag for sag (p. 149 ff.). Hyppigt sete fejl (pp. 145 f., 181 f.) er, at psykologerne ikke adskiller fremlæggelsen af fakta fra egne kommentarer, at de bedømmer børnenes udsagn og reaktioner ud fra voksenlogiske forestillinger eller rentudsagt fordomme, at de hævder at bedømme ikke blot det enkelte udsagns troværdighed, men hele sagens bevismateriale, også selvom de i praksis foretager en begrænset undersøgelse. Netop på dette punkt hævder Diesen med styrke (pp. 209, 213), at psykologerne skal 
begrænse sig til det konkrete udsagn, som skal efterprøves, ja endog at psykologerne ikke skal have adgang til andre beviser i sagen, ikke engang den mistænktes forklaring.

Om psykologens opfattelse af et barns troværdighed stemmer med, om barnet faktisk er troværdigt, kan normalt ikke afgøres med sikkerhed. Vi véd jo ikke med videnskabelig sikkerhed, hvad der virkelig er sket. Lindblads opfølgning af en større sag fra et daghjem i Karlstad, p. 105 ff., udgør delvis en undtagelse, idet den mistænkte i vidt omfang erkendte sig skyldig, hvorfor det er legitimt at tage som udgangspunkt, at der faktisk var sket noget. Forf., selv børnepsykiater, bedømte de implicerede børns forklaringers troværdighed uden forhåndsviden om, hvorvidt den mistænkte havde erkendt, og hvordan retten havde dømt (p. 112). Senere sammenligninger viste en vis, men bestemt ikke fuldstændig overensstemmelse mellem hans opfattelse af vedkommende barns troværdighed og de øvrige elementer i sagen (p. 120). Hvor der var forskel, var det forf.s efterfølgende opfattelse, at den tiltalte formentlig havde tilstået mindre, end han havde gjort (p. $124 \mathrm{f}$.).

Lindblad konstaterede ved sin senere gennemgang af det samlede materiale, at børnenes første forklaringer til forældrene om mulige overgreb var mere detaillerede end de senere forklaringer til politiet (p. 125 f.). Hans konklusion var, at de første forklaringer kan være af stor værdi, samt at et barns forventninger over for politiafhøring kan påføre barnet stress og svække forklaringen, en efter min opfattelse oplagt rigtig konklusion. Om måden at udspørge barnet på indeholder Gumperts materiale værdifulde iagttagelser, således at kompetent udspørgning med åbne spørgsmål gav bedre og mere fyldige svar end ledende og suggestive spørgsmål (p. 163), idet hun tilføjer det selvfølgelige - som ofte overses i praksis - at et ledende spørgsmål ikke nødvendigvis betyder, at svaret på forhånd skal diskvalificeres som falsk, men at det skal analyseres nøjere eller efterforskes yderligere af retten.

Men medens forf. bedømmer de medvirkende psykologer strengt, er bedømmelsen af retternes egen sagsbehandling, særlig retternes udnyttelse eller manglende udnyttelse af psykologernes erklæringer lige så streng.

Sutorius konkluderer i sit andet bidrag Behovet av psykologisk sakkunskap och sakkunnigas roll i processen efter en analyse både af sager, hvor retten og de sagkyndige er uenige, og hvor de er enige (p. $184 \mathrm{ff}$.), at samvirket mellem dommere og sagkyndige til tider helt mangler, til tider er negativt. Det negative samspil kan både vise sig ved, at retten selv uselvstændigt blot lægger den sagkyndiges erklæring til grund, ja kopierer den (pp. 59, 189), og ved, at retten, når erklæringen er særlig dårlig, allerede af den grund blot falder ned på den modsatte konklusion. Om det sidste punkt nævner Sutorius i en fodnote (p. 189), at det er et ud fra materialet antagen hypotetisk mulighed, som hverken kan bevises eller modbevises "så länge domskälen er påtagligt bristfälliga" - danske dommes præmisser er næppe bedre, meget muligt tværtimod.

Diesen, som i sit afsluttende bidrag Bevisvärdering och vittnespsykologisk utsageanalys - metodlikheter och metodskillnader underkaster de sagkyndige en næsten sønderlemmende kritik, skriver i næste åndedræt, at intet, "allraminst domskälen" - der var den igen - taler for, at rettens "hypotesprövning" er bedre end eksperternes (p. 216). Han forkaster derfor en konklusion om, at retten ikke behøver psykologisk hjælp i disse sager. Hans konklusion er nærmest, at retten har brug for anderledes grundig, videnskabeligt præget bistand end de "common sense referenser", som retten selv er henvist til (p. 219), underforstået: som den ikke får bedre hos eksperterne.

De fire forf.'s anbefalinger til retterne balancerer på en knivsæg. Som læser og recen 
sent kan jeg se fornuften ved advarslen mod både at følge de sagkyndige blindt og at forkaste deres anvendelse lige så automatisk, men som dommer vil jeg fortsat have.de største vanskeligheder, både ved afgørelsen om, hvorvidt psykologisk ekspertise overhovedet skal inddrages og i så fald hvordan, og hvordan den sagkyndige udtalelse skal anvendes ved sagens pådømmelse og med hvilken vægt.

Og som dansk dommer er jeg ikke overbevist efter læsningen. Det er bekendt, at danske domstole som også domstole i andre retssystemer nægter at anvende vidnepsykologer både i disse og andre sager; Gumpert nævner (p. 154) De Forenede Stater som det eneste eksempel, men forbigår nærmerebeliggende paralleller - også bogens litteraturliste indeholder kun svenske og amerikanske titler. I denne recension bør det nævnes, at Beth Grothe Nielsens store bog Straffesystemet i børneperspektiv - seksuelle overgreb mod børn i familien i 2001 er udkommet i en stærkt udvidet 2. udgave, altså samtidig med det svenske samleværk, hvis forf. således ikke har haft mulighed for at forholde sig til hendes værk. Selv omtaler hun udførligt den svenske debat. I Danmark forsøger forsvarerne med støtte fra en del af teorien sommetider at inddrage vidnepsykologer, men indtil nu stort set forgæves. Selvom det anmeldte værk har givet mig noget at tænke over, er jeg fortsat nærmest tilbøjelig til at sige, at hvis (eller siden) resultaterne af psykologernes deltagelse ikke er bedre end beskrevet, er der næppe grundlag for at indføre dem hos os.

Derimod er jeg entydigt anerkendende over for de udførte grundige analyser af et meget stort sagsantal. De evige rejsekammerater fordomme og manglende viden spiller måske i ingen saggruppe en større rolle end i sager om sædelighedsforbrydelser mod børn. Forf. har vist os, hvor mange sager der er, hvordan de behandles eller mishandles, og værket bør læses af akademikere og praktikere i alle nordiske lande.

\section{Peter Garde}

Hillerød kriminalret

Anders Bratholm: Mobbing og feighet. En alvorlig mobbesak der skolen, politiet og påtalemyndigheten sviktet groft. Praxis Forlag. 2001. 96 sider.

Mobbing og feighet er skrevet af professor Anders Bratholm og er en beskrivelse af en norsk dreng, Kristoffer, og hans oplevelser som mobbeoffer gennem 3 år. Mobberne var ikke alene jævnaldrende, men også skolelærere, rektor og nærpolitifolk. Og det var ikke kun Kristoffer, der blev offer for mobning, hans mor blev det også. Kristoffers mor havde en aktiv rolle gennem hele forløbet, hvor hun forsøgte at forhindre mobningen og forbedre Kristoffers situation, og hun havde i den forbindelse bl.a. kontakt med Kirke- og Undervisningsministeriet og civilombudsmanden.

Bogen starter med Kristoffers mors egne ord om, hvor ekstraordinært tidligt udviklet Kristoffer var. Det understreges også mange gange gennem bogen, at Kristoffer var og er et velbegavet barn med et stort ordforråd og veludviklede verbale evner, og at han klarede sig godt fagligt i skolen. Det fremgår dog også, at Kristoffer har skiftet skole mange gange i løbet af sit skoleforløb, men der er ikke nævnt nogen form for forklaring på de mange skoleskift.

At dømme ud fra bogens beskrivelse har Kristoffer helt uden tvivl været udsat for flere meget ubehagelige og voldsomme tilfælde af mobning af både psykisk og fysisk karak- 
ter, og han har ydermere modtaget drabstrusler fra mobberne. Mobningen manifesterede sig flere gange i voldelige hændelser og en af disse med en så absurd udgang, at Kristoffer - efter at have anmeldt episoden til politiet - blev sigtet for vold mod politiet.

Bratholm beskriver selv mobbesagen som at stykke aktionsforskning. Bogens første halvdel er en beskrivelse af årene 1993 til 1996. Kristoffer startede i 1993 i 8 . klasse på en ny skole i Oslo. Mobningen af Kristoffer startede kort efter han var begyndt på den nye skole og pågik indtil han i 1996 flyttede til USA og påbegyndte skolegang der. Familien fik kontakt med Bratholm, da problemerne havde stået på i omkring et år, og Bratholm har fulgt sagen lige siden.

Bogens sidste del handler om sagens senere udvikling, herunder familiens forsøg på at få voldsoffererstatning (på familiens vegne ansøgte Bratholm om voldsoffererstatning, og både mor og søn fik tilkendt mindre beløb), samt Bratholms kommentarer om skolens, politiets, påtalemyndighedens, mobbernes, Kristoffers samt hans mors rolle og ansvar i processen - dette er for en stor dels vedkommende en opsummering af den beskrivelse, der findes i bogens første halvdel.

Slutteligt bevæger bogen sig op på et højere plan og beskriver mobbeteori, bl.a. som Dan Olweus og Erling Roland har behandlet det. Bratholm læner sig op af Olweus' mobbedefinition: "En person er mobbet eller plaget når han eller hun, gentagende gange og over en vis tid, bliver udsat for negative handlinger fra en eller flere andre personer". Og der er beskrivelser af, hvad man har gjort for at forebygge mobning i norske skoler, specielt i Oslo-området, bl.a. forsøg med skolemægling. Bratholm fortæller, at Oslo i år 2000 oprettede et kriseteam, som kan kontaktes når der opstår en krisesituation på en skole (fx som følge af mobning), dog benyttes denne kriseordning endnu kun i meget begrænset omfang. Ifølge Bratholm har 10 skoler i Oslo-området taget Olweus mobbeprogram i brug og har dermed (i år 2000) reduceret mobbeproblemerne med $42 \%$. Bratholm bringer også andre - noget forenklede - betragtninger i bogen, bl.a. skriver Barneombudet i forordet, at mobning ikke vil forekomme i en klasse, hvor læreren tager lederopgaven alvorligt.

Ifølge Bratholm har rektor på Kristoffers skole en del af skylden for, at sagen udviklede sig som den gjorde, idet hun ikke ville anerkende problemet, endsige intervenere for at afhjælpe situationen. Rektoren citeres for på et forældremøde at have udtalt, at der ikke forekom mobning på hendes skole, hvortil Bratholm kommenterer: "Man kan undre sig over hvor udbredt denne holdning er i norske skoler". Man kunne have ønsket, at Bratholm havde brugt noget af sin energi på at uddybe denne pointe og diskutere implikationerne af det, i stedet for at bruge så megen plads på gentagelser og overflødige beskrivelser - bl.a. beskrivelser af moderen.

Efter min opfattelse har Bratholm været for følelsesmæssigt involveret $i$ familien til at kunne beskrive sagen på neutral vis. Og der er ærgerligt, for det kunne have været interessant om diskussionen i højere grad var løftet op på et mindre følelsesladet plan.

Bratholm benytter sig hele vejen igennem af navns nævnelse af alle implicerede parter - undtagen mobberne - hvilket må siges at være usædvanligt.

Charlotte Mathiesen Bech

Det Kriminalpræventive Råd 
Dean J. Champion: Probation, Parole, and Community Corrections, Third edition, Prentice Hall, 1999, $512 \mathrm{~s}$.

"Probation, Parole, and Community Corrections" er en bredt anlagt innføringsbok i retningslinjene for og bruken av tilsyn, prøveløslatelse samt ulike straffer og sanksjoner i frihet (samfunnsstraffer) i USA. Det amerikanske retts- og straffesystemet er ganske annerledes enn det nordiske, det er derfor bra at det gis en enkel og lettfattelig beskrivelse av dette. Boken er nok primært ment som innføringsbok for amerikanske studenter og andre uten større forkunnskaper på feltet. Dens hovedmålgruppe synes å være praktikere innen kriminalomsorgen og justisvesenet. Boka er pedagogisk lagt opp med eksempler og spørsmål til ettertanke underveis.

Champion skal ha ros for at han tar opp temaet i sin fulle bredde. Dette har medført at boka har blitt relativt omfangsrik. Han tar for seg hvordan man utarbeider egnethetsvurderinger, bruken og hensikten med tilsyn, konfliktråd (alternative dispute resolutions), boot camps, shock probation, fengsel og arrest (jail), parole, community corrections, hjemmesoning, ulike åpne soningsalternativer, bruken av profesjonelle og frivillige tilsynsførere innen kriminalomsorgen, tilsyn med ungelovbrytere, kvinnelige lovbrytere og andre med spesielle behov. Ved at Champion går inn på så mange relativt omfattende tema så sier det seg også at han ikke har muligheten til å gå i dybden.

Probation, Parole, and Community Corrections er ingen sosiologisk bok. Den stiller ikke spørsmål ved konsekvensene for samfunn og rettsvesen ved at man i 1997 hadde nærmere 7 millioner dømte på ulike samfunnsstraffer og tilsyn. Boka belyser i liten grad om de ulike sanksjonene fungerer og forskning eller evaluering på feltet. Den er definitivt ikke noen representant for kritisk kriminologi, men er i stedet "fanget" av de offisielle forklaringer og logikk. Boka kan muligens fremstå som objektiv for noen lesere, men den representerer helt klart en måte å forstå og forholde seg til disse reaksjonene.

Det er en bok som er "kjekk å ha" som oppslagsbok hvor man kan få svar på spørsmål omkring bruken av en rekke ulike program og soningsalternativer i USA . Det er et spørsmål i hvilken grad nordiske lesere har større nytte av boka som sammenligningsgrunnlag opp mot vårt sanksjonssystem. En kan også spørre om det er noen grunn til å se mot USA for å hente inspirasjon. Boka gir mange gode argumenter for at vi i stedet bør rette blikket mot Europa eller andre deler av verden når det gjelder fremtiden til alternative straffesanksjoner innen rettsapparatet.

\section{Paul Larsson}

Politidirektoratet i Oslo

Bengt Larsson: Bankkrisen, medierna och politiken. Göteborg Studies in Sociology No 3, sociologiska institutionen, Göteborgs Universitet. ISBN 91-972940-9-8. 242 siders tekst samt 38 siders noter, kilder og litteratur.

Lad det være sagt med det samme: Bogen, der er forfatterens afhandling til opnåelse af doktorgraden i sociologi, giver hverken nye juridiske landvindinger eller retssociologiske sådanne. Skuffes den potentielle eller aktuelle læser over dette, er det imidlertid ikke forfatterens fejl, thi forfatterens ærinde har været et ganske andet. Han har på det overordnede plan villet studere samspillet mellem økonomien og samfundet i øvrigt, og på afhandlingsplanet har dette udkrystalliseret sig i bogens to dele: 1) hvorledes blev 1990-ernes 
bankkrise fortolket i offentligheden, og 2) hvorledes forsøgte samfundet at kontrollere økonomiens udvikling ved hjælp af opinionsmæssige, politisk-administrative og retlige midler. Begge dele er opbygget gennem historiske gennemgange og analyser, baseret på henholdsvis ca. 350 artikler, primært lederartikler og debatindlæg og på et antal rapporter, hjemmesider m.v.

Uden nogensinde at blive medrivende, klarlægger bogen på udmærket - og lidt forstemmende og også for en dansk læser deja vue-agtig - vis, hvorledes mekanismerne med nedtoning, forsvar, krav om etik og ansvar og advarslen mod heksejagter afløser hinanden $\mathrm{i}$ en forudsigelig kæde.

\section{Lars Bo Langsted}

Aalborg Universitet

\section{R. A. Duff: Punishment, Communication and Community. Oxford University Press,} Oxford, 2001, 245 sider.

Hvert år dømmer vore domstole tusindvis af mennesker for overtrædelse af strafbelagte regler. Sådan begynder Duff den bog, som her er under anmeldelse, og fortsætter: "What can justify criminal punishment?" (s. xi). Dette spørgsmål er, skriver Duff, uundgåeligt for enhver, som interesserer sig for, hvordan stater bør behandle deres borgere, og Duff tager læseren med på en fascinerende udforskning af spørgsmålet. Det er en forlokkende og interessant udforskning, der efterlader læseren med et vist overblik over de forskellige filosofiske begrundelser for straf, men som undervejs giver den blot nogenlunde eftertænksomme læser uoverskueligt meget stof til eftertanke. Derfor er det - selvom sproget er flydende, klart og let forståeligt - en bog, der tager tid at læse.

Forrest i bogen, dvs. før kapitel 1, findes en knapt 10 sider lang introduktion, hvor siderne er angivet med romertal. Det er $i k k e$ anbefalelsesværdigt at springe introduktionen over. Her redegøres for bogens emne og opbygning samt for en række væsentlige forudsætninger. Duff bemærker f.eks. her, at selvom bogens fokus er på de tilfælde, hvor der idømmes straf ved en domstol, så må det fastholdes, at spørgsmålet om retfærdiggørelsen for straf og straffesystemet er en større og mere kompleks materie. Kun få af dem, der har begået en forbrydelse, idømmes straf, og endvidere udsættes mange, som ikke har begået en forbrydelse, på en eller anden måde for straffesystemet. Intet humant straffesystem kan indrettes således, at alle de og kun de, der har begået en forbrydelse, straffes, skriver Duff, og det må en straffeteori tage højde for.

I første kapitel gennemgås hovedtrækkende i forskellige strafteorier. De inddeles i tre grupper, nemlig konsekvensteorier, retributionsteorier og abolitionsteorier, hver med yderligere underinddelinger. Styrker og svagheder ved hver af de tre retninger påpeges og analyseres, før Duff lægger op til sin egen teori. Som sidegevinst făr læseren et fremragende overblik over hovedtrækkene i disse teorier.

I Duffs egen teori anskues straf som en art kommunikation, der skal kommunikere den bebrejdelse til gerningspersonen, som vedkommende har fortjent for sin handling. Man kunne måske kalde det moralsk kommunikation. Derved skal gerningspersonen gerne angre, ændre sin adfærd og forsone sig med offeret. En sådan forståelse af straffen, skriver Duff, øver retfærdighed både mod teorier, som bygger på retribution eller gengældelse, og mod teorier som er fremadskuende, som fokuserer på konsekvenserne (Duff kalder 
bl.a. dette for "the consequentialist perspective"). Hans teori synes at kombinere elementer fra begge disse retninger. Når staten via straf kommunikerer bebrejdelse, er det udtryk for en bagudrettet begrundelse for straffen (retribution eller gengældelse), mens ønsket om ændring af adfærd er fremadrettet og sigter mod prævention (i.e. er fokuseret på konsekvenserne). Duff understreger dog, at formålet med straffen ikke er afskrækkelse, men derimod at overbevise gerningspersonen og befolkningen om, at visse handlinger er forkerte. Derved skulle overtrædelser gerne kunne forhindres, men det sker altså ved overbevisning om det moralsk rigtige, ikke ved afskrækkelse. Duff understreger, at prævention/afskrækkelse ikke er selve formålet med straf, ifølge hans teori.

Også den tredje retning, "abolitionism" (afskaffelse af straf), integrerer Duff til en vis grad i sin teori. Mens fortalere for denne retning ofte anbefaler en anden type reaktion $i$ stedet for straf, f.eks. mægling, så ser Duff denne type af reaktioner netop som straf, og anser denne type af reaktioner for en særlig velegnet form for straf (bl.a. fordi denne reaktionsform er med til at opfylde Duffs krav om, at straf skal fungere som forsoning mellem offer og gerningsperson).

En normativ teori om retfærdiggørelse af straf må omfatte en bestemt forståelse af fænomenerne kriminalitet, strafferet og stat, skriver Duff i begyndelse af andet kapitel. I Duffs fremstilling er der to hovedtyper af stater: dels den liberale, dels den, som er præget af hensynet til fællesskabet frem for det individuelle ("communitarianism"). Duff beskriver sin teori som byggende på en form for "liberal-communitarianism", i.e. en kombination af de to. Af Duffs beskrivelser er det (i hvert fald for en uindviet læser) ikke helt let at få øje på forskellen mellem Duffs teori og den liberale stat. Han skriver, at mens den liberale statsteori tager udgangspunkt i individet (dets rettigheder, pligter, moral osv.), så tager hans teori udgangspunkt i "individet i samfundet". Pointen er, at i modsætning til Rawls teori mener Duff ikke, at vi kan sætte os ud over vore sociale, familiemæssige og samfundsmæssige bindinger. Disse bindinger er os givne, ikke noget vi vælger. Teorien betyder bl.a., at forbrydelser ikke blot opfattes som forkerte handlinger over for individer (i.e. det umiddelbare offer), men tillige mod hele samfundet og samfundets normer. Derfor er det begrundet, ja endog nødvendigt, at samfundet reagerer mod forbrydelser; det er ikke blot et anliggende mellem to individer. Samtidigt betyder fællesskabselementet - de samfundsmæssige og familiemæssige bindinger m.v. - at alle borgere er en del af fællesskabet, også dem, der begår forbrydelser.

I tredje kapitel gennemgår Duff mere detaljeret, hvad der ligger i hans forståelse af straf som kommunikation, og nogle i denne henseende ideelle former for straf analyseres, bl.a. mægling. Duff analyserer også, hvordan disse straffe virker på forskellige typer af gerningspersoner, navnlig om det er hensigtsmæssigt at anvende straf, forstået som kommunikation, over for personer, som forbryder sig igen og igen. Han mener, at samfundet må fortsætte med at behandle disse personer, som alle andre lovovertrædere, dvs. via straf at udtrykke bebrejdelse, og dermed håbe på, at de vil vise anger, ændre adfærd og undskylde deres forbrydelse, selvom dette ikke nødvendigvis sker.

I øvrigt synes det at være en vigtigt pointe i Duffs teori (hvilket også elaboreres i tredje kapitel), at der ikke lægges op til en "dem og vi" holdning eller retorik. Vi er alle medlemmer af samfundet, vi kan alle fristes, og vi har alle krav på at blive behandlet med respekt og som en del af samfundet. Det følger af teorien om straf som kommunikation, skriver Duff. Det er således helt centralt, at den moralske kommunikation ikke lægger op til eksklusion af dem, som begår kriminalitet, snarere tværtimod; kommunikationen er 
udtryk for, at vi alle, både dem der straffer, og dem der straffes, er en del af fællesskabet.

I fjerde kapitel behandler Duff spørgsmålet om strafudmåling. Enhver acceptabel strafteori må være i stand til at genere tilfredsstillende regler for, hvordan straffen skal udmåles. Der gives et godt overblik over proportionalitetsprincippets afskygninger og betydning for dette spørgsmål. Desuden gives en nærmere analyse af spørgsmålet om, hvordan Duffs teori passer i tilfælde, hvor dommeren står over for personer, der gentagne gange har begået alvorlige og farlige forbrydelser. Duff kan ikke helt udelukke, at livslang frihedsstraf måske bør anvendes, men denne type straf passer ikke umiddelbart ind $\mathrm{i}$ teorien, fordi der med en sådan straf ikke kommunikeres en bebrejdelse, der muliggør ændring af adfærd og forsoning. Han er, skriver han, usikker på, hvad han skal konkludere om sådanne tilfælde.

I femte og sidste kapitel drøfter Duff det, som vel nok må være den største indvending imod hans teori. Teorien synes at være ædel, konsistent og argumenterne holdbare, men det hele synes samtidigt en anelse teoretisk eller metafysisk. Duff skriver indledningsvis i dette kapitel, at hans teori er en normativ, ideel redegørelse for, hvad straf bør være. Som samfundet og straffesystemet er indrettet i øjeblikket, kan teorien ikke fungere som retfærdiggørelse for straf, og Duffs konklusion er, at hans teori ikke kan anvendes uden ændringer i det nuværende straffesystem. Ideen med en strafteori er ikke at retfærdiggøre det eksisterende straffesystem, men at transformere systemets indhold og kontekst så straffen kan blive, hvad den bør være. Afstanden mellem Duffs teori og praksis er derfor ikke noget, som gør teorien inadækvat; det påpeger ufuldkommenheden i det praktiske liv, skriver Duff. Og denne påpegning af det nuværende straffesystems ufuldkommenhed og uhensigtsmæssighed er tankevækkende. Men det svækker nu alligevel teorien, hvis den bygger på forudsætninger, som er svært opnåelige i det praktiske liv. Forudsætningerne for Duffs teori er krævende. Han konkluderer som nævnt, at teorien kun kan anvendes i tilfælde af en kollektiv anstrengelse for ændring af straffesystemet og ændring af samfundets eksklusion af dele af befolkningen. Ved kollektiv anstrengelse forstår Duff ikke bare regeringens og institutionernes handlinger, men "demands on all citizens, and especially on those who are not unjustly excluded or disadvantaged by the political community" (s. 201). Det er store krav at stille, og Duffs socialt bevidste, ikke-ekskluderende teori om straf er næppe foreneligt med det fremherskende syn på kriminelle og kriminalitet.

Det ændrer naturligvis ikke ved det faktum, at bogen er uhyre velskrevet, tankevækkende og byder på en meget rammende kritik af eksisterende straffesystemer. Bogens emne er (for at bruge Duffs egne ord) "unavoidable for anyone, who cares about how states should treat their citizens" (s. xi). Og dét er vel netop nærværende tidsskrifts læserkreds?

\section{Thomas Elholm}

Direktoratet for FødevareErhverv

Liv Finstad: Politiblikket. Pax Forlag A/S, Oslo 2000, 366 sidor.

Liv Finstad, professor vid Institutt for kriminologi vid Universitetet i Oslo, har med denna bok publiserat sitt första, större arbete om polisen. Det är fråga om en kvalitativ studie om polisarbetets innehåll och form i stort-närmast med ett antropologiskt arbetssätt. Boken är resultatet av ett längre fältarbete i Oslo polisdistrikt och dess fem polisstationer 
samt ett ännu längre efterföljande analysarbete. Dess tema är förankrat i ordningspolisens vardagsarbete, som främst studeras med utgångspunkt i deltagande observationer. Ordningstjänsten är polisarbetets ryggrad och det är främst de bilpatrullerande poliserna, som bestämmer ordningstjänstens dagordning. Utgångspunkten är polisens allmänna dagliga, verksamhet, där polisen utlovar trygghet, lag och ordning för Oslos invånare. Boken handlar främst om händelser och relationer, som oftast inte tematiseras i polisens dagliga verksamhet.Det är fråga om händelser, som utförs och upplevs som sjävklara och rutinmässiga av polisen och förmodligen också av allmänheten. I projektet har LF varit, speciellt intresserad av att få kunskap om polisens roll i tolkningsprocessen-hur polisen läser omgivningen. Det handlar i sin kärna om vad polisen ser, hur människor och situationer observeras och definieras samt vad polisen faktiskt gör.

"Politiblikket" är LF:s huvudbegrepp för att utforska polisens perspektiv, förståelse och handlingar. Det är alltså hennes egen "forskarblick" av vad "polisblicken" närmare är, som jag nu med min "bokanmälarblick" skall granska. Min uppfattning är att det nästan åttaåriga arbetet med boken utgör en högt kvalificerad forskning om det grundläggande "egentliga" polisarbetet-det hittills grundligaste nordiska polisforskningsarbetet-och av hög internationell klass.

LF har disponerat sin bok i 12 kapitel. Jag börjar med att ge en översikt av de olika, kapitlens huvudfrågor för att sedan se närmare på några av de viktigaste kapitlen och avsluta med några kritiska synpunkter, som eventuellt kan vara till nytta för en engelsk utgåva av boken, som jag hoppas skall komma, dock något förkortad.

Kap.1 "Trygghet, lov og orden" behandlar huvudmålsättningen för polisen, som är att sätta allmänhetens behov för trygghet, lag och ordning i Oslo polisdistrikt i centrum och att försöka uppfylla dessa krav så snabbt som möjligt.

Kap. 2 "Arbeidets organisering" är en beskrivning av ordningspolisens ramar och procedur-främst vid de fem polisstationerna men också vid vissa andra, specialenheter inom ordningsavdelningen.

Kap-3 "Publikumsbestillinger og politiinitiativer" är en första inblick i polisordningstjänstens arbete. Vilka uppdrag får polisen från allmänheten respektive vilka uppgifter tar polisen själv initiativ till?

Kap-4 "Mens vi venter" behandlar det allra viktigaste - ett underkommuniserat tema nämligen vad polisen gör "när det inte är något att göra". LF formulerar här ordningstjänstens rytm som att "polisen väntar på att något helst inte skall ske".

Kap-5 "Politi og røver" handlar om hur övervakning och kontroll eller "stopp og sjekk" blir en metod under väntetiden, på anrop, där polisblicken fördjupas och i sin kärna blir ett "mistankeblikk"-främst mot "kjenninger".

Kap. 6 "La rettferdigheten skje fyldest" behandlar närmare förhållandet mellan mål och medel vid händelser, som polisen tar initiativ till.

Kap-7 "La nåde gå for rett?" handlar främst om förhållandet mellan polisen och allmänheten i stort. Vad är typiskt - samarbete eller konflikt? När låter polisen nåd gå före rätt respektive rätt före nåd?

Kap.8 "En god kollega" vänder polisblicken mot polisen själv och ser bla närmare på vilka oformella ideal som konkretiseras i det dagliga kollegiala samarbetet. Polisyrket i Norge bedöms inte vara en enhetlig poliskultur utan ett varierat kollegialt sällskap.

Kap. 9 "Synlige og usynlige minoriteter" undersöker vidare polisens sammansättning och gränserna för vem polisen anser sig representera. 
Kap.10 "Politikritikken og politiblikket" tar utgångspunkt i polisens upplevelse och förståelse av fysisk maktanvändning och maktmissbruk. Var går gränsen enligt polisen respektive allmänheten? Vad skiljer dessa åt? Vilka samhällsmässiga reaktioner är aktuella, när polisen, kollektivt respektive poliser enskilt begår fel?

Kap.11 "Det kritiske politiarbeidet" drar linjerna tillbaka till bokens tidigare kapitel om polisblicken och polisblickens samhällsmässiga konsekvenser. Där behandlas också vilken del av den samhällsmässiga arbetsdelningen, som polisens ordningstjänst tar sig an. Polisens prioriteringar, roll och funktion i samhället anses inte bara visa på polisens utan också på samhällets kvalitet.

Kap.12 "Som gjest hos politiet" är metodkapitlet, som inte bara handlar om undersökningens förlopp, utan också är ett efterord, som ger en tillbakablick på fältarbetet och hela forskningsprojektet.

Jag skall nu gå närmare in på några av de viktigaste kapitlen, och börjer med kapitel 3 och 5 . I polissociologisk forskning beskrivs ordningspolisens bilpatrullerande arbete som publikumdominerat, händelsestyrt och reaktivt. LF's studie visar att så är fallet men att polisens egna initiativ (det proaktiva arbetet) också är mycket betydelsefullt och nästan lika omfattande som det reaktiva. Med utgångspunkt i hennes 50 tjänstetillfällen som utgör mer än 400 timmars patrulltjänst i fältarbetet, registrerade hon 426 händelser, varav $58 \%$ var uppdrag från allmänheten. och $42 \%$ var polisens egna initiativ. Den lediga tiden för de 50 tjänstetillfällena bedömer LF vara i genomsnitt 30-50 \%. Polisblicken blir under denna tid en blick för att finna "røver" eller "slask", som är utgångspunkten för LF:s diskussion om vad ordningspolisen menar med "egentligt polisarbete". Den tydligaste förnimmelsen av polismässig handling sker enligt LF under natt eller mörker. Den konklussionen bygger på hennes systematisering av hur de 426 händelserna fördelar sig efter publikumbeställningar och polisinitiativ under dag, kväll och natt. Polisinitiativen visar stor variation med $4 \frac{1}{2} 2$ gånger fler händelser på natten jämfört med dagen.

I sin mest renodlade form innehåller "det egentliga polisarbetet" i ordningstjänsten enligt LF elementen bilpatrull, mörker och jakt. Bilpatrullens sammansättning har enligt LF konsekvenser för arbetsstil och inställning till arbetet. När ordningsavdelningen har lägst genomsnittsålder och dessutom är den mest synliga avdelningen utåt, präglas det synliga polisarbetet av unga mäns stil, presentation och arbetsbegrepp. Föreställningen om att "det egentliga polisarbetet" är att fånga tjuvar påverkas enligt LF mer av pojkdrömmar än av kolleger. Men LF har ett varnande ord. Bilpatrullering i större städer är ofta den empiriska polisforskningens utgångspunkt och i urvalet av tema och presentation kan det därför hända att denna polisforskning indirekt har bidragit till att underbygga föreställningen om att "egentligt polisarbete" är att fărga tjuvar.

"Politiblikket" från en polisbil medför att polisen speciellt fokuserar på "kjenninger" och personer som uppfattas som kjenninger. Utsikten från en polisbil bestämmer i hög grad "politiblikkets" innehåll-patrulleringsformen bestämmer patrulleringsinnehållet enligt LF .Hon drar också en direkt parallell mellan forskningsmetod och patrulleringsform. Forskningsmetoden jämför hon med polisens patrulleringsform-medlet. Men forskningsmetoden skall väljas utifrån problemställningarna. Forskarens problemställningar jämför hon med polisens prioriteringar-målet. Men metoden (Patrulleringsformen) påverkar också enligt LF vilka problemställningar(Prioriteringar), som är möjliga att belysa. (s. 122). LF ger också i kap. 3 s. 67 och kap. 5 s. 126 en Idealtypisk beskriv- 
ning av kännetecknen på "publikumbeställningar" och, "polisinitiativ", som är ett viktigt bidrag till förståelsen av polisvardagen.

I kap. 7 konstaterar LF att av de 426 händelserna på de 50 tjänstetill fällena slutar över 80 \% som "ordnat på stället". I avsnittet "Politiblikk og publikumsblikk" ger LF flera olika instruktiva exempel, på hur samma händelser kan uppfattas helt olika beroende på om utgångspunkten är polisens eller allmänhetens perspektiv. Hon redovisar också hur hon valt exemplen, vilket i sin tur visar hur svårt det är att särskilja, "forskarblicken", "polisblicken" och "publikumblicken". Hon framhåller i en not på s. 203 hur exemplen kommit till. Exemplen på "polisblicken" har LF själv observerat eller fått återberättade i intervjuer och samtal. Exemplen på "publikumblicken" är sammanfattningar som bygger på egna observationer i hennes projekt, hennes egna upplevelser från andra sammanhang och berättelser från den allmänhet, som hon mött i projektet. Framställningen bygger därför enligt LF på några föreställningar, som hon gör sig av hur situationer kan tolkas. De olika perspektiven på "samma" händelse bildar också en viktig bakgrund för kritik av polisen - se kap.10.

På sidan 210 förekommer en diskussion om polisen som gäst och värdskap, som är mer förbryllande än upplysande. Kap.7 avslutas med en idealtypisk beskrivning men där saknas en viktig faktor i den annars utförliga "skönsanalysen", nämligen olika "Typer Folk", som förekommer som en viktig faktor i andra kapitel i boken. -

Kap. 10 utgör den längsta och mest nyskapande analysen i boken. Frågan om det finns mycket eller litet polisvåld hänger nära samman med hur handlingar tolkas. I avsnittet "Hendelser jeg kunne ha unnvaert" redovisar LF egna observationer från hela sitt fältarbete. Här möter vi det problem, som finns i varje analys i boken av "politiblikket" och som LF själv är medveten om. Hon framhåller, att forskaren inte är någon neutral person mellan polis och allmänhet. Personliga värderingar och kunskap om polisinstruktionens överordnade princip för polisingripande spelar enligt henne in. "Alt i alt er nok mitt forskerblikk på konfliktfylte hendelser fremledes mer et "publikumsblikk" enn et "politiblikk"."(s.281). Som helhet visar LF:s framställning på att man kan lägga dessa tre "blickar" på polisens maktanvändning. När "hur situationer definieras" läggs till grund, kan formuleringar som "ord mot ord" omskrivas till "upplevelse mot upplevelse". Upplevelsen är enligt LF alltid situationsbestämd och hon pekar ut tre konkurrerande "märkeslappar" på "samma" handling, nämligen "politivold", "ulovlig maktbruk" och "uklar/unødvendig maktbruk". De olika orden speglar enligt LF olika syn på handlingens förhistoria, innehåll och orsak. I en idealtypisk beskrivning av olika förståelser av polisens fysiska maktanvändning sammanfattar LF de tre orden på följande sätt: (1)Polisvåld är uppsåtligt och grovt oaktsamt, ett socialiserings- och kulturproblem, dvs "polisvåldskultur", (2)olovlig maktanvändning är uppsåtligt och grovt oaktsamt, ett individuellt problem, dvs, "brodne kar", och (3)oklar/icke-nödvändig maktanvändning är en felbedömning, en yrkesrisk, dvs "olycksfall i arbetet". (s.296).

LF behandlar också hur polisens maktanvändning bör kontrolleras och redogör därvid för två olika kontrollsystem - kollegial kontroll, som är tvåspårigt, och straffrättslig kontroll, som är enspårigt. När LF sammanfattar polisblickens automatiserade tolkning av gränsen mellan nödvändig och icke-nödvändig maktanvändning och därmed självjustisens grund, hänger några element ihop på ett bestämt sätt. "Gode kolleger" är involverade i olycksfall i arbetet - även efter en felbedömd situation och felhandling behåller man arbetet; ifall man inte upprepar sig. "Brodne kar" begår däremot lagbrott - man utnyttjar 
samhällets förtroende för polisen och kan därför inte fortsätta som polis. I utgångspunkten består självjustisen därför enligt LF av ett tvåspårigt system - ett reaktionssystem för "lagbrott" begått av "brodne kar" och ett reaktionssystem för "olycksfall i arbetet", begått av vanligen "gode kolleger". Med risk för att missa många nyanser lämnar sedan LF en idealtypisk beskrivning av den tvåspåriga självjustisen, som är ett viktigt bidrag till polisvardagen (s. 307).

LF:s bok handlar främst om hur polisblicken koncentreras på observation, tolkning och handling i förhållande till tre olika Typer Folk - polisens "kjenninger", allmänheten i stort och poliser i stort. Ordningstjänsten bedömer och handlar mest i relation till enskilda handlingar och enskilda personer. Polisblicken riktad mot polisyrkets strukturella kännetecken och polisens roll $\mathrm{i}$ den samhällsmässiga arbetsdelningen är jämförelsevis litet utvecklad och detsamma gäller polisarbetets inbyggda risker. Men i kap.11 behandlar LF relativt kortfattat dessa problem.

LF's förståelse av polisarbetet eller hennes "forskarblick" handlar om att polisen inte är tillräckligt känslig för allmänhetens och "kjenningers" upplevelse av polisarbetet och polisens maktanvändning. Hennes botemedel är att polisen i högre grad uppmärksammar hur polishandlingar upplevs, även när polisen använder laglig makt och även när allmänheten och "kjenninger" upplevs som "vanskliga". Risken för att använda mer makt än nödvändigt och speciellt risken för att andra upplever detta, kommer enligt LF alltid att finnas i polisarbetet (s. 324).

Metoderna i det dagliga ordningspolisarbetet år enligt LF ett handlingssätt med inbyggd risktagning. Kärnan i uppsökande polisarbete som t ex stopp-och check-metoden är alltild baserad på diskrimination eller att skilja mellan misstänkt och icke-misstänkt person. Ett rutinmässigt praktiserande av en misstankebaserad polisblick riskerar enligt LF att sänka kontrolltröskeln. Ordningstjänsten innebär mer misstankebekräftelse än många andra former av polisarbete och det är inte bra om polisen stannar i denna tjänst hela yrkeslivet. (S.329-330). I alla polishandlingar ligger enligt LF ett budskap. "Budskapet ligger i presentasjonen. Presentasjonen er budskapet” (s. 331).

I bokens sista kapitel - metodkapitlet men också efterordet - gör LF ett försök att lämna en inblick i forskarens verkstad. Hon lyckas på ett utmärkt sätt belysa de fördelar men också svårigheter, som hon mött med projektets arbetssätt. Detta kapitel anser jag vara det viktigaste i hela boken, då det visar på vilka möjligheter för generaliserbarhet beträffande polisens vardagsarbete, som finns i LF:s bok.

LF började sitt forskningsprojekt 1992 med en ansökan till Oslo polisdistrikt. Från att ha studerat socialarbetarens yrkesroll, som mest är inriktad på hjälp, förklarar hon, att hon nu vill studera polisens yrkesroll, som mest är inriktad på kontroll. Hon anser, att skillnaden är tvetydig, då det finns kontroll i hjälpen och hjälp i kontrollen. Polisen är på många sätt hjälpapparatens förstalinjetjänst. Många av de existentiella frågorna blir enligt henne gemensamma för de båda yrkesgrupperna. I utgångspunkten var LF mest intresserad av "menneskelige belastninger i politiyrket og krisemestring" (s. 339). Samtidigt som projektet förbereddes utnämndes hon till styrelseledamot vid Polishögskolan. Det var därför enligt henne flera orsaker till att hon började sitt projekt med sitt fältarbete vid årskiftet 1992/93. Detta fältarbete skulle vara till 1995, varefter analysarbetet fortgick under ca fem år.

Metoden fältarbete var självklar för LF och där ingick deltagande observation, intervjuer och skriftligt källmaterial. Forskningsmetoden väljs, i överensstämmelse med 
valda problemställningar, teoretiskt perspektiv och material. Från att från början ha varit intresserad av polisens krishantering kom så småningom det vardagliga, rutinmässiga, odramatiska polisarbetet i centrum för LF:s intresse. Det är inte bara så att problemställningarna bestämmer metoden, utan det är också tvärtom; detsamma gäller möjligheten att få ett bra material. LF:s fältarbete utgör omkring $1^{1 / 2} 2$ års arbete främst i Oslo polisdistrikt med bas i de fem polisstationerna.På alla stationerna deltog hon tillsammans med ordnings-, kriminal- och förebyggandetjänsten men inte lika mycket i varje aktivitet och på varje ställe. Boken tar sin utgångppunkt $\mathrm{i}$ ordningstjänsten och där var LF med främst som 3:e eller 4:e man i bilpatrulltjänsten i sammanlagt omkring 600 timmar. Datamaterialet från Oslo består dessutom av 35 kvalitativa intervjuer. Förutom fältarbetet i Oslo gjorde LF några korta besök vid ett norskt "lensmanskontor" och en vecka vid Bostonpolisen i USA. På bägge platserna intervjuade hon också polisen. Dessutom reste LF våren 1994 tillsammans med "opptaksnemnda" vid Polishögskolan för att samla datamaterial om "opptakssystemet" och deltog i ca $2 / 3$ av "opptaket" det året.

Om sina data framhåller LF att de har samma skevhet som annan polisforskning generell polissociologi bygger oftast på material från den bilpatrullerande ordningspolistjänsten i större städer och polisens arbete är i hög grad nationellt och lokalt förankrat. Polisens vardag är mycket olika och beroende på var i landet och när på dygnet vardagen utspelar sig. LF:s data är främst hämtade från Oslos fem polisstationer - mest från ordningstjänsten. Främst skall boken läsas som en bok om ordningstjänsten i Oslo men LF betonar att många av ordningstjänstens dilemman berör kärnan i hela polisverksamheten. Hon betonar också att hon försökt visa en viss vetenskaplig försiktighet med att dra generella slutsatser av materialet.

Varje forskningsmaterial har nödvändigtvis en tidsmässig eftersläpning. Observations- och intervjuperioden varade fram till omkring 1995. Efter denna tid har LF hållit sig orienterad och tagit hänsyn till organisationsförändringar inom polisen. Men ingenting är enligt LF nytt i ordningspolisens dagliga verksamhet. En fråga är emellertid vad omläggningen från Polisskola till Polishögskola eventuellt har betytt och kan komma att betyda på sikt - 1995 kom den första utexaminerade kullen ut i polisarbetet.

Fältarbetets längd är angivet till 11/2 års arbete eller ca. 600 timmar. LF är osäker på vad hon skall räkna, vilket enligt henne är ett viktigt poäng både principiellt och praktiskt och säger något om fältarbetets natur. Det var arbete, när hon deltog i polisens arbetstid de 600 timmarna. Men boken bygger inte bara på rena forskningsmetoder som deltagande observation, intervjuer och genomgång av skriftligt material. Man blir exponerad av andra informationer och deltar i samtal med andra personer. Men viktigast är enligt LF att ett fältarbete också innebär att utveckla och fördjupa mänskliga relationer. Genom projektet blev LF bekant med många poliser; några har blivit mycket goda vänner och LF lever nu tillsammans med en politiførstebetjent. Hennes sociala nätverk har enligt henne betytt mycket för det material, som boken bygger på. Hon har fătt veta ännu mycket mera genom personliga relationer efter det att det "egentliga" fältarbetet avslutats. Men ett problem handlar enligt LF om att upprätthålla en nödvändig analytisk distans, vilket hon anser sig ha gjort genom diskussioner med forskarkolleger och andra personer utan polisbakgrund.

LF hade själv tagit initiativet till sitt forskningsprojekt om polisen, när hon blev utnämnd till styrelseledamot av Polishögskolan. Hon kom som objuden "gäst" till polisen med en förhistoria som poliskritisk kriminolog - hon hade bl. a deltagit i den norska 
polisvåldsdebatten. Efter att projektet pågått en tid frågade hon poliserna hur och $\mathrm{i}$ vilken grad de påverkats av hennes närvaro. Alla svarade enligt henne att det inte gjort någon skillnad - den viktigaste kommentaren var "vi har ingenting att dölja". Men å andra sidan är det enligt henne otänkbart att forskarnärvaron inte skulle betyda någonting - alla präglas vi av med vem vi umgås men så småningom uppför vi oss mer spontant, när vi blir mer kända med varandra. Varje fältarbete är en balansgång mellan närhet och avstånd. Att bli alltför "husvarm" ("go native" = "bli infödd") är enligt LF den största dödssynden hos en forskare.

LF framhåller att hennes perspektiv och inställning till polisen har ändrat sig efter hennes erfarenheter i samband med forskningsprojektet. Hon anser, att hon ser polisen mer än tidigare från polisens perspektiv. Kännedom till polisen över tid har medfört att det är svårare för henne än förr att uttala sig entydigt om en del förhållanden.

Denna bokanmälan har inte kunnat göra full rättvisa för den grundläggande, omfattande och högt kvalificerade analys, som LF:s bok utgör. Om jag skulle föreslå ytterligare fördjupningar i analysen, skulle den ha kunnat omfatta faktorer som (1)grundläggande värderingar, (2)samhällssyn och människosyn, (3)den norska samhällsstrukturen och (4)kvantitativ redogörelse för grundmaterialet.

Den kvalitativa forskningen har stora fördelar men ställer också frågen om representativitet och generaliserbarhet. Hur representativt är LF:s grundmaterial på 426 registrerade händelser under de ca 400 timmarnas observation i bilpatrulltjänsten, dvs ca 1 händelse per timme i genomsnitt? Som jämförelse kan nämnas att Oslo polisdistrikt årligen făr c:a 150.000 anrop om hjälp från allmänheten eller i genomsnitt c:a 20 per timme. Vidare, hur representativa är hennes 426 händelser fördelade på publikumbeställningar och polisinitiativ under dag, kväll och natt? I en not på s. 97 nämner hon talen för 11 dagturer-72 händelser, 21 kvällsturer - 158 händelser och 18 natturer-196 händelser. Ytterligare, vi vet inte hur många polisers arbete, som LF kunde observera under bilpatrullerandet. Var det ofta samma poliser, hur många var kvinnor, unga respektive äldre, eller tillhörde minoriteter som LF behandlar i kap.9? Vi vet inte mycket om LF-.s intervjuer annat än vad hon kortfattat nämner $\mathrm{i}$ en not på $\mathrm{s}$. $282 \mathrm{om}$ sina 35 kvalitativa intervjuer av Oslopolisen om dess maktanvändning. Vi vet heller inte något närmre om vilket skriftligt källmaterial, som LF använt.

Men dessa invändningar förtar inte grundintrycket av boken, som är en synnerligen upplysande inblick i vad polisarbete är, och som måste bli en nödvändig läsning för alla, som berörs av polisyrket. LF:s bok om norsk polis från år 2000, Lars Holmbergs doktorsavhandling "Politiets skøn i rettssociologisk belysning" om dansk polis från 1999 och Gunnar Ekmans doktorsavhandling "Från text till batong. Om poliser, busar och svennar" om svensk polis från 1999 är tre viktiga böcker för förståelsen av nordiskt polisarbete, vilka alla kompletterar varandra på ett förtjänstfullt sätt så att vi bör kunna dra vissa generaliserbara slutsatser om polisarbetet i våra demokratiska rättsstater.

\section{Hans Klette}

Lunds universitet 
David Kauzlarich \& Ronald C Kramer: Crimes of the American Nuclear State. At Home and Abroad. Northeastern University Pres, Boston 1998.

Bokens grundläggande frågeställning är om USA under åren har agerat kriminellt i sin utveckling av atomenergi och kärnvapen. Författarna besvarar den frågan jakande och redovisar ett flertal flagranta exempel på hur personlig integritet helt eliminerats i den nationella säkerhetens namn. Det kanske mest upprörande är de experiment med att utsätta människor för strålning som redovisas i kapitel 6. Under åren 1945-47 utfördes experiment med plutoniuminjektioner för att se hur den mänskliga kroppen reagerade. I flera fall handlade det om personer intagna på sjukhus med cancer. Endast i något enstaka fall informerades patienterna om syftet med injektionerna.

Mellan 1963-1973 utsattes 131 amerikanska fångar för radioaktiva experiment. Då amerikanska stridspiloter visat sig vara oroliga för hur deras fertilitet påverkades av att transportera kärnvapen, bestrålades fångarnas testiklar. Informationen om riskerna var minst sagt bristfällig.

Därtill har det förekommit en omfattande radioaktiv nedsmutsning av miljön. "What is clear is that most, if not all, of the nuclear weapons production facilities in the United States have illegally contaminated the environment for over fifty years" (s.112). Amerikanska cancerinstitutet uppskattar att miljontals barn utsattes för radioaktiv strålning enbart i samband med kärnvapensprängningarna i Nevada under 1950-talet, "perhaps 10,000 to 75,000 of them might develop thyroid cancer for this exposure" (s.122).

I boken presenteras en mängd såväl upprörande som beklämmande fakta. Men bakgrundsavsnitten är alldeles för långa. Stora delar skulle med fördel kunnat utgå. Med en radikal strykning hade materialet räckt till ett par riktigt bra vetenskapliga artiklar.

\section{Janne Flyghed}

Stockholms universitet

Tore Bjørgo, Yngve Carlsson og Thomas Haaland (2001) Generaliserte hat-polariserte fellesskap; Om konflikter mellom ungdomsmiljøer $i$ en norsk by. NIBRs PLUSS-SERIE 4-2001, 240s.

I denne bog beskrives resultaterne af en undersøgelse i Kristiansand, som er et led i et omfattende forskningsprojekt vedrørende bandefænomenet i fire Norske byer - Oslo, Drammen, Kristiansand og Stavanger. Projektet startede med støtte fra Justitsministeriet (1999) og blev udvidet og overgik til Norges Forskningsråds Velfærdsprogram (2000). I Kristiansand blussede konfrontationen mellem nynazister på den ene side og antiracister/indvandreungdom på den anden side kraftigt op i efteråret 2000. Der var diskussion mellem kommune, politi og Fædrelandsvennen (avis) om, hvordan situationen skulle tolkes. Var der tale om racistisk vold med nynazister som angribere og antiracister/indvandreungdom som ofre, eller drejede det sig om mere ligeværdige aktører, hvor konflikterne ikke havde meget at gøre med racisme, nazisme og politik? På baggrund af konfrontationerne og diskussionen om tolkning ønskede kommunen en undersøgelse af forholdene.

For at få indblik i de voldelige konflikter i nogle af Kristiansands ungdomsmiljøer har forskerne valgt at interviewe 50 unge fra eller tæt på miljøet. Forskerne havde ikke tid til selv at komme tæt på miljøet, hvorfor respondenterne hovedsageligt blev udvalgt af 
ansatte ved politiet og kommunen. 20 respondenter var eller havde været tilknyttet det nynazistisk miljø, 10 respondenter tilhørte det multietniske "Valla"-miljø, og 20 respondenter var knyttet til forskellige andre miljøer, men kan karakteriseres som "mod nynazisterne". Det lykkedes ikke at interviewe de mest centrale ledere fra miljøerne, men en række kernemedlemmer blev dog interviewet. Materialet er suppleret med interviews med 18 voksne (forældre, politifolk, kommunalt ansatte).

Resultaterne af undersøgelsen beskrives i 6 kapitler. Overskrifterne af kapitler er: Framveksten av et rasistisk ungdomsmiljø (kap. 3), Nynazisternes fiender: "Hiphop'ere", "Valla" og "antirasister" (kap. 4), Polariseringen av ungdomsmiljøet (kap. 5), Forvaltning av respekt: Hevn og selvtekt (kap. 6), Konflikter og territorium (kap. 7) og Demografi og geografi (kap. 8). Den sidste og afsluttende kapitel (9) indeholder en opsummering og anbefalinger.

Undersøgelsen vedrører hovedsageligt nynazister og Valla. Nynazisterne består af skinheadgruppen Boot Boys (gadevold, øl og uniform) og den mere raceideologiske Vigrid (racekrig mod zionister). Mange af nynazisterne har haft en problematisk opvækst omsorgssvigt, dårlig skolegang, offer for mobning osv. De fleste kommer fra en norsk "underklasse". "En kjennetegn ved den norske underklassen er at den møter innvandrere og flyktninger mer direkte enn middelklassen. De møtes i samme segment på arbejdsmarkedet, og de møtes som naboer. Slike møter kan være både positive og hjertelige, men de kan også være vanskelig og konfliktfylte" (s. 204). Ifølge forskerne står begrebet Valla for to forskellige fænomener. Nogen bruger det som betegnelse for et mobiliseringsnetværk bestående af ca. 200 unge, mens andre med Valla forstår en gruppe på ca. 10 kernemedlemmer og 10 til 20 faste deltagere. Oprindelig var Valla en bande, men karakteriseres nu mere som et netværk. Både nynazisterne og Valla har ændret karakter over tid. De tilpasser sig omstændighederne. At konflikten mellem de to parter har eksisteret - i mere og i mindre grad - i syv år, er atypisk for Norge. Kernespørgsmålet - hvad handler konflikten om - bliver ikke entydigt besvaret. På den ene side er der tale om racistisk vold. "I disse tilfellene er det mer på plass å snakke om rasistiske overgrep enn om konflikter mellom to symmetriske parter. En del av de voldelige handlingene begått av nynazisternes modparter må kunne sees som en direkte reaksjon på - og til dels som selvforsvar mot - disse overgrepene" (s. 206). På den anden siden påpeger forskerne, at en del af konflikterne bunder i ønsket om at opnå respekt, magt og territorial dominans. Specielt den territoriale dominans bliver fremhævet som årsag til konflikterne i efteråret af 2000 - dem der foranledigede undersøgelsen. De skriver: "Det multietniske ungdomsmiljøet stengte nynazistene ute fra sentrum, og mobiliserte for å banke opp nynazister som våget å vise seg der. Etter hvert som stadig flere av de gjenværende nynazistene ble så gamle at de ville ta del i voksenlivet i sentrum, ble kontrollen over sentrum en dominerende konflikt som tilspisset seg kraftig høsten 2000" (s. 215).

Analysen af situationen virker meget overbevisende. Ud fra analysen drager forskerne anbefalinger. Som udgangspunkt understreger de, at en fornuftig tiltag består af en balancegang mellem en positiv inkluderingsstrategi og en mere repressiv gransesætningsstrategi. Efter forskernes mening er det muligt at opløse den nynazistiske miljø. "Ved å prioritere rask etterforskning av lovbrudd som deltakere i miljøet har utøvet, rask iretteføring og prioritering i soningskøen av sentrale lederskikkelser i miljøet, og samtidig satse på positive tiltak overfor øvrige medlemmer i miljøet, kan man bringe miljøet under sin 'kritiske masse'. Hvis miljøet først bringes under et visst antall deltakere, kan gruppen 
bli så lite attraktiv at den ikke tiltrekker seg nye" (s. 219). Forskerne er mindre begejstret for at opløse Valla, for netværket har flere funktioner end at begå kriminalitet og vold. Desuden er det formentligt også meget svært at opløse netværket på grund af dets struktur og omfang. Anbefaling er at rense netværket for de kriminelle elementer. Ellers formulerer forskerne anbefalinger, som har en mere alment karakter og kan indgå i en hvilken som helst undersøgelse af ungdoms- eller bandekriminalitet.

Forskningsprojektet har uden tvivl givet mere indblik i baggrunden af konflikterne. Det er i sig selv værdifuldt. Jeg er derimod ikke overbevist om, at anbefalingerne (på længere sigt) bidrager ret meget til løsningen af problematikken. Der bliver nævnt en række forskellige tiltag, som kræver mange ressourcer, hvis de skulle gennemføres, og er dermed - som samlet pakke - efter min vurdering urealistisk. Paragraf 9.4.1. har som overskrift "De realistiske målene - å løse opp et miljø og å dempe et annet" (s. 219). Måske vil forskerne antyde, at netop denne anbefaling skal prioriteres. Men også selvom det lykkes at opløse det nynazistiske miljø, er det sandsynlig, at det hurtigt kan blusse op igen, hvilket faktisk skete i Kristiansand for nogle år siden. Så længe den underliggende problematik eksisterer, vil der opstå konflikterne. Men som sagt, analysen i sig selv er meget givende, og bogen er en god investering for alle, der er interesseret i ungdomskonflikter, bander og gadevold.

\section{Peter Kruize}

Københavns Universitet

Ben Emmerson QC och Andrew Ashworth QC (Hon): Human Rights and Criminal Justice, First Edition, Sweet \& Maxwell, London, 2001, 657 sid.

Syftet med boken är att i detalj undersöka påverkan av europeisk människolagstiftning och speciellt Europakonventionen på det kriminalrättsliga systemet $\mathrm{i}$ England och Wales och speciellt på tillämpningen av The Human Rights Act 1998. Även om denna lag endast tillämpats under nio månader, menar författarna att det är möjligt att identifiera några viktiga teman i de engelska och skotska domstolarnas avgöranden. Detta gäller bl a proportionalitetsprincipen, fair trail (rättvis rättegång) enligt Europakonventionens Artikel 6, oskyldighetspresumtionen enligt Artikel 6 p 2., skyddet mot "self-incrimination" och gränsdragningen mellan civil, administrativ och straffrättslig förhandling i relation till Artikel 6.

Boken inleds med en ovärderlig innehållsförteckning på ca. 60 sidor av UK Cases, Statutes, Statutory Instruments, Rules, EHCR och EU Cases samt EU och International Legislation.

Boken består av två huvuddelar. Del 1 på 145 sidor behandlar Europakonventionenfrämst dess procedur och tolkningsprinciper(speciellt domstolens tolkningstekniker)samt den engelska The Human Rights Act 1998. Del 2 på 410 sidor omfattar 14 kapitel med följande kapitelrubriker: The Definition of a Criminal Charge, Rights Relating To Arrest And Detention In Police Custody, Entry, Search And Seizure, Intrusive Surveillance, The Substantive Criminal Law, The Burden And Standard Of Proof, Retrospectivity And The Principle Of Legal Certainty, Issues Of Criminal Responsibility, Double Jeopardy, Bail, Aspects Of Criminal Procedure, Criminal Evidence, Sentencing And Related Issues, Appeales, The Rights of Victims of Crime. 
Speciellt det sista kapitlet om Brottsoffrens Rättigheter är viktigt därför att det behandler en "modernisering" av Europakonventionen. Konventionens huvudsakliga syfte är att skydda individers rättigheter från övergrepp av stater. Men Strassbourgdomstolen har erkänt att om de rättigheter som tillkännages i konventionen skall skyddas effektivt, måste vissa stadganden tolkas som om de medför positiva skyldigheter för staten. Kapitlet undersöker dessa positiva skyldigheter, som skyddar brottsoffer och potentiella brottsoffer samt andra- speciellt vittnen-, vars rättigheter kan kränkas under brottmålsprocessen. Det gäller främst statens skyldigheter (1) att förhindra - genom ett effektivt operationellt kriminalrättsligt system - kränkningar av rättigheter under Artikel 2 och Artikel 3, (2) att ha strafflagar som straffbelägger kränkningar av Artikel 2,3 och 8,(3) att undersöka påstådda brott mot Artikel 2 och 3 samt åtala när bevisning föreligger och motivera med skäl, och (4) att skydda de processrättsliga rättigheterna för brottsoffer och vittnen under brottmålsprocessen. Tre former av skydd är aktuella under (4); (a)skydd för identiteten av ett vittne, som riskerar att bli utsatt för repressalier, har erkänts som legitim grund för begränsningar i den tilltalades rättigheter enligt Artikel 6, (b)skydd för vittnen för kränkningar av deras rättigheter vid förhör-korsförhör under domstolsförhandlingar och (c)skydd för brottsoffer och vittnen beträffande konfidentiella medicinska arkiv. Det rör sig i stort under 1-4 om att skydda liv, skydd mot inhuman och degraderande behandling, rätt till frihet och personlig säkerhet, rättvis rättegång, skydd mot privatlivet-den personliga integriteten.

Boken har också ett viktigt Appendix på ca. 80 sidor med europeiskt material om Europakonventionen och dess viktigaste ändringar genom protokoll 11, samt UK material - främst The Human Rights Act 1998 och The Criminal Appeal(Amendment) Rules 2000. Dessutom avslutas boken med ett utförligt Index på 16 sidor. Detta är en mycket viktig bok, vars 1:a upplaga säkert snabbt kommer att följas upp av nya upplagor. Analyserna av Strassbourgdomstolens avgöranden är mycket utförliga och kan vara till stor vägledning för nordiska myndigheter vid tilllämpningen av den europeiska människorättslagstiftningen, som blir allt utförligare och mer och mer komplicerad att följa.

\section{Hans Klette}

Lunds Universitet 